Journal Wetenskap Health

\title{
The Effect of Job Satisfaction and Organizational Commitment on the Performance of the Special Hospital for Mothers and Children in South Sulawesi Province
}

\author{
Azhiima Firliyah Andi Ara ${ }^{1}$, Syahrir A. Pasinringi ${ }^{1}$, Sangkala ${ }^{2}$ \\ Corresponding Email: firliyahsuhardi@yahoo.co.id \\ ${ }^{1}$ Department of Hospital Management, Faculty of Public Health, Hasanuddin University, \\ Indonesia \\ ${ }^{2}$ Department of Administrative Sciences, Faculty of Social and Political Sciences, \\ Hasanuddin University, Indonesia
}

\begin{abstract}
The low performance of the Regional Special Hospital belonging to the Province of South Sulawesi illustrates the quality of consumer services that affect hospital income. This study aims to analyze the effect of job satisfaction on organizational performance, the effect of organizational commitment on organizational performance, the effect of job satisfaction on organizational commitment, and the effect of job satisfaction on organizational performance directly and indirectly through organizational commitment of the Mother and Child Hospital of South Sulawesi Province. This type of research is a quantitative study using an analytical observational study with a cross sectional study design. The sample was taken using stratified random sampling so that the sample in this study included medical, nursing, midwifery and non-medical personnel, totaling 190 respondents at the Siti Fatimah Mother and Child Hospital and Mother and Child Hospital Mother and Child Motherland, South Sulawesi Province. The results showed that there was a relationship between job satisfaction and organizational performance $(0.000)$, there was a relationship between organizational commitment and organizational performance (0.000), there was a relationship between job satisfaction and organizational commitment (0.000), and job satisfaction was the most influential variable on performance $(32,10 \%)$ compared to organizational commitment $(21.90 \%)$. Therefore, it is expected that the hospital is able to maintain and develop the supporting dimensions of job satisfaction and organizational commitment of its employees in order to achieve organizational performance as expected.
\end{abstract}

Keywords: Job Satisfaction, Organizational Commitment, Organizational Performance, Special Hospital, Maternal and Child Hospital

\section{Introduction}

In order to improve the ability to provide quality services to this community, various efforts have been made by the government. So far, the results have shown a fairly good improvement in health. Especially for the procurement of health facilities such as hospital facilities, the progress that has been achieved has shown conditions as expected. Seeing this reality, it must be admitted that the government's efforts to date have succeeded in increasing the number of hospitals in Indonesia (Khoirunnisah et al., 2019).

Article Info:

Received: April 12, 2021

Revised: May 14, 2021

Accepted: May 27, 2021

Copyright (C) 2021, Journal Wetenskap Health, Under the license CC BY-SA 4.0 
Human resources are one of an organization's most significant assets, since they are the only resources capable of driving other resources. Thus, human resources are a critical component that must be maintained by an organization in order to meet the demands that the business constantly meets in order to address any current difficulties. As a result, the organization's primary objective is to preserve high-quality human resources (Muhid \& Susiawan, 2015). One form of the quality of human resources is reflected in the performance of employees. To be able to achieve this quality, the company must be able to improve employee performance. Therefore, human resources need to be managed properly to improve organizational performance.

According to Yelboğa (2012) Performance measures of a job play an important role in research and practice. The success or failure of the organization depends on the performance of the employees in the organization. The higher the employee's performance, the greater the chances of an organization's success, and vice versa, the lower the employee's performance, the greater the probability of an organization's failure.

Problems in services in the health sector, especially regarding hospitals, have begun to be revealed in several studies. For example, in RSUD Banjarnegara there are $30 \%$ more complaints from inpatients that are intended for nursing services, this can also indicate the low work performance of nurses (Wahyuni, 2007). The service referred to in this study is the friendliness and responsiveness of nurses to patients who are still below the quality standards set by the hospital management. Based on Siregar's (2008) research, other problems that have been revealed in 4 provinces in Indonesia, namely DKI Jakarta, North Sumatra, North Sulawesi, and East Kalimantan regarding the performance of nurses are $47.4 \%$, this percentage shows that nurses do not have a detailed job description. In writing, $70.9 \%$ of nurses have never attended training held in the last 3 years, $39.8 \%$ of nurses are still carrying out non-nursing duties, and there is no development of a monitoring and evaluation system for nurses' work performance.

The work by Laffaldano and Muchinsky in Ouedraogo \& Leclerc (2013) has become a standard reference in this field. This casts doubt on not just the nature of the link, but also on the extent to which these two variables are correlated. According to their findings from a meta-analysis of over 200 empirical correlations across 24 research, the average association between work happiness and work performance is modest. Such a low correlation coefficient suggests that work happiness is not a "reliable" predictor of work success. As a consequence of these findings, it is sometimes said that the link between work happiness and performance is really indirect rather than direct; nonetheless, it is affected by other variables. Nonetheless, the available research provides a variety of other explanations and arguments for this insignificant association (Ouedraogo \& Leclerc, 2013).

The Dharmais Cancer Hospital (RSKD) for Mother and Child Siti Fatimah in South Sulawesi Province and RSKD for Mother and Child in South Sulawesi Province are hospitals belonging to the government of South Sulawesi Province class C. The achievement of performance in the number of patient visits in the Outpatient Installation of RSKD IA Siti Fatimah Province South Sulawesi experienced a decline in 2016-2018 with a decline in 20162017 of $2 \%$ and a decline in 2017-2018 of 9\%, so it is known that the average decline is 5\%. The number of visits in 2016 was 11,617, in 2017 it was 11,373, and in 2018 it was 10,392. Meanwhile, RSKD IA Pertiwi has fluctuated, where in 2016-2017 it increased by 5\% and then decreased in $2017-2018$ by $19 \%$ so that the average decrease was $7 \%$ with the number of patient visits in 2016 as many as 9,860, in 2017 as many as 10,326, and in 2018 as many as 8,412 . 
The number of patient visits to the Inpatient Installation of RSKD IA Siti Fatimah also decreased in 2016-2017, decreased by $6 \%$ and in 2017-2018 decreased by $23 \%$ so that the average decline was 14\% with the number of visits in 2016 was 4,186, in 2017 as many as 3,953 , in 2018 as many as 3,040. While in the Inpatient RSKD IA Pertiwi also decreased in 2016-2017 decreased by $13 \%$ and in $2017-2018$ decreased by $11 \%$ so that the average decrease was $12 \%$ with the number of visits in 2016 as many as 5,442, in 2017 as many as 4,722 , and in 2018 as many as 4,184.

In addition, this also affects the average income at the Siti Fatimah Mother and Child Hospital for 2016-2018, which is Rp. 11,419,110,680 and the average income of the Mother and Child Hospital for the Motherland of South Sulawesi Province in 2016-2018 is Rp. $18,434,873,039$. In addition, in terms of achieving the Minimum Service Standards (SPM) at the Siti Fatimah Mother and Child Hospital in South Sulawesi Province and the Dharmais Cancer Hospital (RSKD) Mother and Child in South Sulawesi Province, when viewed from the report, it has reached the standard except for patient satisfaction which is still below standard. However, if it is observed that service activities are carried out, there are still elements that have not reached the Minimum Service Standards. The BOR achievement in the Siti Fatimah Mother and Child Hospital also decreased every year in 2016-2018 so that the average was $68 \%$ and in the Mother and Child RSKD the average BOR only reached $61 \%$.

In this regard, one of the factors that is expected to affect the performance of the hospital organization is employee job satisfaction. According to Bakotic (2016) who conducted research on the relationship between job satisfaction and organizational performance on 5,806 employees, it is known that organizational performance is also influenced by employee job satisfaction. This is in line with the results of Risnakes (2017) which outlines that to achieve the performance of hospital organizations in Indonesia it is necessary to achieve job satisfaction where the results show a high category of $26.1 \%$, a medium category of $50.0 \%$. However, there are still $23.9 \%$ in the Low category.

Employee job satisfaction and organizational commitment are very necessary considering that employees are the parties who provide the best service for patients so that they try to be more active and desire to achieve optimal results (Evant, 2018). Due to the Siti Fatimah Mother and Child Hospital's and South Sulawesi Province's poor performance, this research will concentrate on the work satisfaction and organizational commitment of staff at the Mother and Child Hospital of South Sulawesi Province.

\section{Methods}

This study was done in the Siti Fatimah Mother and Child Hospital and the Mother and Child Hospital in South Sulawesi Province. The research is quantitative in nature and employs an observational study design with a cross sectional methodology. The population of this research consisted of all staff at the Siti Fatimah Mother and Child Hospital in South Sulawesi Province and the Mother and Child Hospital in South Sulawesi Province, a total of 377 individuals. The sample size for this research was chosen using stratified random sampling, which resulted in a sample size of 190 individuals.

The data collecting tool is a questionnaire, with work satisfaction and organizational commitment as independent variables, and performance as the dependent variable. Univariate analysis was utilized to get an overview of the research topic by detailing each variable employed in the study and the respondents' characteristics. Univariate analysis entails the description of respondents' characteristics, the description of research factors, and the 
crosstabulation of respondents' characteristics and research factors. The bivariate analysis was used to determine the connection between two variables, namely the independent and dependent variables. The Chi Square test was utilized as the statistical test. The logistic regression test was used to do multivariate analysis.

\section{Results and Discussion}

Table 1. Results of Logistics Regression Test Together Variable Job Satisfaction and Organizational Commitment to The Performance of RSKD I.A Pertiwi and RSKD I.A Siti Fatimah South Sulawesi Province

\begin{tabular}{|c|c|c|c|c|c|c|}
\hline Variable & B & S.E & Forest & Itself. & $\begin{array}{c}\operatorname{Exp}(B) \text { or Odd } \\
\text { Ratio }\end{array}$ & $\begin{array}{c}\text { R Square } \\
(\%)\end{array}$ \\
\hline \multicolumn{7}{|l|}{ RSKD Pertiwi } \\
\hline Job Satisfaction & 2.772 & 1.354 & 4.189 & 0.041 & 15.991 & 13.50 \\
\hline $\begin{array}{l}\text { Organizational } \\
\text { Commitment }\end{array}$ & 1.574 & 1.130 & 1.940 & 0.164 & 4.824 & 6.30 \\
\hline \multicolumn{7}{|l|}{ RSKD Fatimah } \\
\hline Job Satisfaction & 3.612 & 1.242 & 8.457 & 0.004 & 37.041 & 43.20 \\
\hline $\begin{array}{l}\text { Organizational } \\
\text { Commitment }\end{array}$ & 2.205 & 1.023 & 4.648 & $\mathbf{0 . 0 3 1}$ & 9.068 & 33.40 \\
\hline \multicolumn{7}{|c|}{ Combined PROVINCIAL RSKD IA } \\
\hline Job Satisfaction & 3.984 & 1.145 & 12.099 & 0.001 & 53.744 & 32.10 \\
\hline $\begin{array}{l}\text { Organizational } \\
\text { Commitment }\end{array}$ & 1.830 & 0.785 & 5.432 & 0.020 & 6.235 & 21.90 \\
\hline
\end{tabular}

Source: Primary Data, 2021.

The frequency distribution based on the characteristics of the sample in the research location, most of the respondents in the nursing profession were 89 respondents $(46.84 \%)$. Judging from the work unit/installation, most of the respondents from the inpatient unit were 40 respondents $(21.05 \%)$. In terms of gender, most of the respondents were female, as many as 143 respondents $(75.26 \%)$. In terms of education, most of the respondents with the last bachelor's degree were 77 respondents $(40.53 \%)$. Judging from the working time, most of the respondents worked 40 hours or more a week as many as 103 respondents (54.21\%). Judging from the work status, most of the respondents working status as civil servants/permanent workers are as many as 140 respondents $(73.68 \%)$. In terms of age, most of the respondents were aged 20-35 years, as many as 111 respondents (58.42\%). Judging from the years of service, most of the respondents who worked more than 5 years were 125 respondents $(65.79 \%)$.

Respondents' assessment of research variables stated that some respondents stated that they had job satisfaction which was in the satisfied category at the Special Hospital for Mothers and Children in South Sulawesi Province as much as $94.21 \%$. have organizational commitments that are in the high category at the Special Regional Hospital for Mother and Child, South Sulawesi Province as much as 91.58\%. has a relatively high (good) organizational performance in the Special Hospital for Mother and Child in South Sulawesi Province, which is $87.89 \%$

It is well established that the association between the independent and dependent variables exists, with job satisfaction factors having a substantial association with 
organizational commitment. Job satisfaction has a substantial link with organizational performance in the Hospital Installation, with a p value of 0.0000 .05 . The organizational commitment variable in the Hospital shows a strong link with organizational performance, with a $\mathrm{p}$ value of 0.0000 .05 .

The results of the multiple logistic regression test on the variable job satisfaction and organizational commitment to the performance of the Mother and Child Hospital Motherland Hospital in South Sulawesi Province show that the variable with the greatest influence was job satisfaction with a value of $\mathrm{p}=0.0410 .05$, indicating that the job satisfaction has a positive effect on the performance. According to the description of the hospital analysis's findings, the multiple logistic regression test of job satisfaction and organizational commitment variables on the performance of RSKD I.A Fatimah, South Sulawesi Province, revealed that all variables had an effect on organizational performance. The work satisfaction variable has a stronger effect on the performance of RSKD I.A Fatimah, South Sulawesi Province, with a value of $p=0.0040 .05$. While organizational commitment has a $p$ value of 0.0310 .05 , it is inferred that it has a higher $P$ value than job satisfaction. The results of the overall analysis of the Mother and Child Hospital of South Sulawesi Province indicate that the multiple logistic regression test of job satisfaction and organizational commitment variables on organizational performance in the Mother and Child Hospital of South Sulawesi Province revealed that all variables had an effect on organizational performance. With a $p$ value of 0.0010 .05 , it can be stated that work satisfaction has a stronger impact on organizational performance at the Special Hospital for Mothers and Children in South Sulawesi Province. Organizational commitment has a $p$ value of 0.0200 .05 , which is larger than work satisfaction.

Job satisfaction has an influence on the performance of staff at the RSKD Mother and Child Hospital in South Sulawesi Province, according to research hypothesis 1 (H1). According to the statistical analysis, there is a significant effect of 0.0000 .05 , which means that the alternative hypothesis (Ha1) is accepted, indicating that the first hypothesis "there is an effect of job satisfaction on employee organizational performance in the Mother and Child Hospital in South Sulawesi Province" is proven. The findings of this research corroborate those of Merry Ristiana M (2013), who found a positive and substantial link between work satisfaction and employee performance. These findings corroborate Bakoti's (2016) study, which found a strong association between employee job satisfaction and organizational performance in both directions, but with a relatively mild intensity. A thorough examination reveals that the association between work satisfaction and organizational performance is greater than the association between job satisfaction and organizational performance. One may argue that work satisfaction has a greater influence on organizational performance than organizational performance has on job satisfaction. To substantiate this assertion, the article's study findings indicate that the majority of work satisfaction characteristics have an effect on organizational performance.

This link implies that the more pleased workers are with their employer, the higher their job performance and outcomes, or vice versa. If an employee is satisfied with his job, his morale will improve. This incentive may make it simpler to accomplish the company's objectives. Wibowo (2015) contends that work satisfaction is a predictor of performance due to the modest association between work satisfaction and performance. As a result, it may be stated that employee work satisfaction has an effect on performance. When employees are satisfied with their jobs, their performance improves, and vice versa. 
This is consistent with Donnely et al(2004) .'s thesis, which claims that work satisfaction may result in an increase or drop in performance. As a result, workers who are content with their jobs will be more productive than those who are unsatisfied. If workers are unsatisfied with their jobs, this will result in a decline in performance.

The second research hypothesis (H2) asserts that organizational commitment has an influence on staff performance at the South Sulawesi Mother and Child Hospital. According to the statistical analysis, there is a significant effect of 0.0000 .05 , which means that the alternative hypothesis (Ha2) is accepted, implying that the second hypothesis "there is an effect of organizational commitment on employee organizational performance in the Mother and Child Hospital in South Sulawesi Province" is proven.

These findings corroborate those of (Khan \& Din, 2010), who discovered a favorable correlation between employee dedication and performance. These data suggest that organizational performance may be enhanced by employee commitment. This is also consistent with the findings of the study (Fauzan \& Sumiyati, 2018) that organizational commitment shown by workers of PT Bank Mandiri Tbk. Cirebon area (Yos Sudarso) has a favorable and substantial effect on employee performance at PT Bank Mandiri Tbk. Cirebon area (Yos Sudarso). According to a more extensive examination of the amount of factors' impact on experimentally gathered data, the organizational commitment program performed by PT. Bank Mandiri Plc. in the Cirebon region (Yos Sudarso) has a 61.3 percent effect on staff performance. While the remaining 38.7 percent is impacted by unidentified variables.

Organizational commitment is considered an important work behavior that has a potential influence on organizational effectiveness (Shiva \& Suar, 2010). The premise behind this idea is the fact that organizational commitment increases employees' desire to stay in the organization, improves their performance, and stimulates their maximum efforts to achieve organizational goals, all of which are considered essential for organizational effectiveness (Srithongrung, 2011). Therefore, determining whether organizational effectiveness is affected by the level of employee commitment has received legitimate attention.

The findings of this investigation are corroborated by Veramitha et al (2016), In relation to the influence of organizational commitment on field personnel' performance at the Coco Pertamina gas station, MT According to Haryono, organizational commitment has a considerable impact on performance, and the normative commitment component is the most influential component of organizational commitment on employee performance.

Numerous elements have been identified as motivators of commitment. For instance, Ongori (2007) claims that employee commitment and loyalty are heavily reliant on work enrichment, employee empowerment, and salary. Camilleri (2002) investigated some of the main antecedents that contribute to making employees committed to the organization using regression methods and analysis of variance and found that education level, personality and position are the significance that determines individual employee commitment level. The findings further reveal that education level and position are significantly stronger for the sustainability and normative dimensions of employee commitment, while personality is significantly stronger for the sustainability and effective dimensions.

Job satisfaction, according to research hypothesis 3 (H3), has an influence on the organizational commitment of staff at the RSKD Mother and Child Hospital in South Sulawesi Province. According to the statistical analysis, there is a significant effect of 0.000 0.05, which means that the alternative hypothesis (Ha3) is accepted, implying that the third 
hypothesis "there is an effect of job satisfaction on employee organizational commitment in the Mother and Child Hospital in South Sulawesi Province" is proven. This is consistent with the findings of Akbar et al. (2016), who found a positive correlation between work satisfaction and employee organizational commitment, implying that high work satisfaction increases organizational commitment considerably and vice versa.

These findings corroborate Wagiman \& Sutanto's study (2015) It is well known that the investigation of the influence of work commitment on job satisfaction showed that work commitment had a positive and statistically significant influence on job satisfaction. This suggests that the more the employee's devotion to the job, the greater the employee's job happiness. The analysis's findings are also corroborated by Mathis's (2009) expert definition, which states that people who are relatively satisfied with their jobs are more likely to be committed to the organization, and people who are committed to the organization are more likely to receive greater satisfaction. Additionally, Akbar et al. (2016) performed study demonstrating that job satisfaction, which includes contentment with superiors, contentment with rewards, happiness with working circumstances, and happiness with colleagues, has a considerable value influence on organizational commitment.

According to research hypothesis 4 (H4), work satisfaction and organizational commitment have an effect on the Mother and Child Hospital's performance in South Sulawesi Province. Based on the statistical analysis, it is known that the most influential variable is job satisfaction, with a $\mathrm{P}$ value of 0.0010 .05 , and organizational commitment has a $\mathrm{P}$ value greater than organizational commitment, implying that the alternative hypothesis (Ha4) is accepted, implying that the fourth hypothesis "There are variables that have the greatest influence.

By working to improve other aspects of job satisfaction (i.e. work, supervision, and co-workers), which show a moderate level of satisfaction, but which is also positively correlated with organizational commitment, human resource officers can also achieve greater organizational commitment. One surprising finding by (Suma \& Lesha, 2013) is that although the level of satisfaction is low with respect to salary/incentive aspects, there is no correlation with organizational commitment. In other words, even though these employees are very dissatisfied with their remuneration, this does not mean that they are not committed to the organization.

Research findings from Suma \& Lesha (2013) indicates that employees in Shkoder Municipality are quite satisfied with the nature of the work itself, the supervision they receive, and their co-workers. They are less satisfied with promotion opportunities and most dissatisfied with the salary they receive. There is also a positive correlation between work, supervision, co-workers and promotion, but no relationship between salary/incentives and organizational commitment.

By engaging in these activities, organizations may boost employee engagement, and workers should be aware of their involvement. Organizations must give enough resources to workers, including information, material resources, and staff training and development. Additionally, the firm should define rewards and incentives for workers clearly and clarify the link between good employee performance and remuneration.

\section{Conclusion}

The results indicated that there was a relationship between job satisfaction and organizational performance (0.000), that there was a relationship between job satisfaction and 
organizational commitment $(0.000)$, that there was a relationship between job satisfaction and organizational commitment $(0.000)$, and that job satisfaction was the most influential variable on performance $(32,10 \%)$ when compared to organizational commitment (21.90 percent ). As a result, it is envisaged that hospitals will be able to sustain and enhance their workers' supporting dimensions of work satisfaction and organizational commitment in order to achieve desired organizational performance.

\section{References}

Akbar, F., Hamid, D., \& Djudi, M. (2016). Pengaruh Kepuasan Kerja Terhadap Komitmen Organisasional Dan Kinerja Karyawan (Studi pada Karyawan Tetap PG Kebon Agung Malang). Jurnal Administrasi Bisnis S1 Universitas Brawijaya, 38(2), 79-88.

Bakotić, D. (2016). Relationship between job satisfaction and organisational performance. Economic Research-Ekonomska Istraživanja, 29(1), 1-13. https://doi.org/10.1080/1331677X.2016.1163946

Camilleri, E. (2002). Some Antecedents of Organizational Commitment: Result from an Information Systems Public Sector Organization. Bank of Valletta Review, 25(25), $1-29$.

Donnely, J., James, G., \& Ivancevich, M. (2004). Organizations: Behaviour, Structure and Process. McGraw-Hill Companies Inc.

Evant, J. S. (2018). Advisor: Kasmirudin Business Administration Programme-Faculty of Social and Political Sciences- University of Riau, Bina Widya Campus Jl. H. R Soebrantas KM.12,5 Simpang Baru Panam, Pekanbaru 28293. Jurnal Online Mahasiswa Fakultas Ilmu Sosial Dan Ilmu Politik Universitas Riau, 5(1), 1-13.

Fauzan, A. H., \& Sumiyati. (2018). Pengaruh Komitmen Organisasi terhadap Kinerja Karyawan PT. Bank Mandiri. Tbk. Area Cirebon (Yos Sudarso). Pengaruh Komitmen Organisasi Terhadap Kinerja Karyawan, 1-20. http://antologi.upi.edu/file/Jurnal_Pengaruh_Komitmen_Organisasi_Terhadap_Kine rja_Karyawan.pdf

Khan, M. R., \& Din, Z. (2010). The impact of organizational commitment on employees Job Performance. European Journal of Social Sciences, 15(3), 292-298.

Khoirunnisah, K., Chotimah, I., \& Maryati, H. (2019). Faktor-Faktor Yang Berhubungan Dengan Kinerja Pegawai Loket Pendaftaran Di Rumah Sakit "X" Bogor Tahun 2018. Jurnal Mahasiswa Kesehatan Masyarakat, 2(4), 268. https://doi.org/10.32832/pro.v2i4.2239

Mathis, R. \& J. (2009). Human Resource Management. Salemba Empat.

Muhid, A., \& Susiawan, S. (2015). Kepemimpinan Transformasional, Kepuasan Kerja dan Komitmen Organisasi. Jurnal Psikologi Indonesia, 4(03), 304-313.

Ongori, H. (2007). A Review of the Literature on Employee Turnover. African Journal of Business Management, 8(3). https://doi.org/10.30845/aijss.v8n3p4

Ouedraogo, A., \& Leclerc, A. (2013). Job satisfaction and organizational performance: Evidence from canadian credit union. Journal of Organizational Culture, Communications and Conflict, 17(1), 35-50.

Srithongrung, A. (2011). The causal relationships among transformational leadership, 
organizational commitment, and employee effectiveness. International Journal of Public Administration, 34(6), 376-388. https://doi.org/10.1080/01900692.2011.569917

Suma, S., \& Lesha, J. (2013). Job Satisfaction And Organizational Commitment: The Case Of Shkodra Municipality. 9(17), 41-51.

Veramitha, N., Suparwati, A., \& Wigati, P. A. (2016). Persepsi Pasien Rawat Inap Klas III terhadap Responsiveness Pelayanan Dokter dan Perawat di Rumah Sakit Umum Daerah Raa Soewondo Pati. Jurnal Kesehatan Masyarakat (E-Journal), 4(1), 55-64.

Wagiman, S., \& Sutanto, H. A. (2015). Job Satisfaction Mediates Relationship Between Organizational Commitments And. 132-143.

Wahyuni, S. (2007). Analisis Kompetensi Kepala Ruang dalam Pelaksanaan Standar Manajemen Pelayanan Keperawatan dan Pengaruhnya Terhadap Kinerja Perawat dalam Mengimplementasikan Model Keperawatan Profesional. Tesisi, 112.

Yelboğa, A. (2012). Dependability of job performance ratings according to generalizability theory. Education and Science, 37(163), 157-164. 